\title{
CMA, health advocacy groups laud tobacco control, dementia investments in budget
}

$\mathrm{T}$ obacco control measures in the 2014 federal budget earned praise from the Canadian Medical Association (CMA) and the Canadian Cancer Society, which pointed to the life-saving benefits of an increase in taxes on cigarettes, cigars and other tobacco products.

Finance Minister Jim Flaherty's announcement Feb. 11, 2014 of a nearly $24 \%$ increase in the tried-and-true sin tax on tobacco will net Ottawa a whopping \$685 million extra in 2014/15 alone - unless of course the additional $\$ 4.03$ cents on a carton of 200 cigarettes drives droves of smokers to quit altogether.

That outcome would thrill the Canadian Cancer Society, says Pamela Fralick, the organization's president and chief executive officer.

"We are absolutely delighted. This is about saving lives," she told $C M A J$ in a post-budget interview. "Whenever there's an increase in price it affects behaviour, particularly with young people."

Five million Canadians still smoke and smoking-related illnesses add at least $\$ 4.4$ billion a year to direct health care costs, says Fralick. Lung cancer remains the number one cause of cancer-related deaths in both men and women.

The budget also allocated $\$ 91.7$ million over five years to shore up the RCMP's antitobacco smuggling initiatives, perhaps in recognition that higher tobacco prices can result in an increase in sales of contraband cigarettes, thus necessitating more smuggling. The funding will be used to create a Geo-spatial Intelligence and Automated Dispatch Centre, and to coordinate and deploy radar, sonar and other unmanned ground sen- sors designed to detect movement in high-risk areas along the border.

The CMA also welcomed the tax hike on tobacco products and linked the increased prices to a likely reduction in smoking.

"We know that one of the biggest

Canadian Institutes of Health Research (CIHR) to invest in research on dementia, through the Canadian Consortium on Neurodegeneration in Aging.

The Alzheimer Society of Canada had asked the government to create a larger, Canadian Alzheimer Disease and Dementia Partnership. The funding is "but one critical step" to help Canada fight dementia, the society said in a news release.

The research funding, combined with the newly announced Canadian Employers for Caregivers Plan will improve the lives of Canadians affected by dementia, says Mimi Lowi-Young, the organization's chief executive officer. Among other things, the plan will identify promising workplace practices that support caregivers. Details will be announced later this year. By 2040, family members will be devoting 1.4 billion hours per year to caring for loved ones with dementia, the society estimates. This represents \$11 billion in lost income and nearly 230000 full-time jobs.

Although there were no details about how much of the $\$ 15$ million increase to CIHR would go to the dementia consortium, the CMA also called the investment "a good first step" towards a panCanadian health care strategy for seniors.

things people can do to improve their health is to not smoke, so any move that encourages people to quit - or better yet, never take it up in the first place ... then we applaud it," Dr. Louis Hugo Francescutti, CMA's president, said in a news release.

CMA also lauded the federal government for providing extra funding to the

\section{$\$ 70$ million for the North}

In addition, the CMA is pleased that Ottawa has promised the three territories $\$ 70$ million in new funding to improve health services by reducing reliance on outside health experts and cutting down on medevac flights. 
However, Nunavut, the Yukon and the Northwest Territories had asked for $\$ 90$ million - $\$ 30$ million in each of the next three years - to improve access to health care in the North, NWT's Minister of Health and Social Services Glen Abernethy told $C M A J$ in an interview. The request was to replace the Territorial Health System Sustainability Initiative, which expires Mar. 31, 2014.

The territories had also asked for
\$13 million a year to manage mental health and addiction programs and to finance an aging-in-place strategy, $\$ 2$ million per year for innovation, and $\$ 15$ million per year for access to tertiary and specialized care, including medical travel.

Abernethy doesn't know if the new money, which he calls "good news," will replace the existing program, and says the territories have not yet received the details.
"We are pleased that the federal government supports ongoing territorial efforts to improve access to health care," says Abernethy.

The territories' small populations spread over large and often inaccessible areas makes delivering high-quality health care and access to specialized care difficult, Abernethy stressed. Laura Eggertson, Ottawa, Ont.

CMAJ 2014. DOI:10.1503/cmaj.109-4728 